Bryn Mawr College

Scholarship, Research, and Creative Work at Bryn Mawr College

Classical and Near Eastern Archaeology Faculty

Research and Scholarship

Classical and Near Eastern Archaeology

1977

\title{
The Plataian Tripod and the Serpentine Column
}

Brunilde S. Ridgway

Bryn Mawr College, bridgway@brynmawr.edu

Let us know how access to this document benefits you.

Follow this and additional works at: http://repository.brynmawr.edu/arch_pubs

Part of the Classical Archaeology and Art History Commons, and the History of Art, Architecture, and Archaeology Commons

\section{Custom Citation}

Ridgway, Brunilde S. 1977. The Plataian Tripod and the Serpentine Column. American Journal of Archaeology 81:374-379.

This paper is posted at Scholarship, Research, and Creative Work at Bryn Mawr College. http://repository.brynmawr.edu/arch_pubs/67

For more information, please contact repository@brynmawr.edu. 
much more necessary commodities of foodstuffs, or, more likely, metals, which have not been preserved in their original form. Punic prospecting and control of metal resources in the western Mediterranean and Atlantic are well known, as is the Etruscan possession of iron and copper resources (one recalls the Etruscan bronze industries famous in antiquity). Possibly, the Carthaginians supplied something, perhaps tin, to Etruscan cities in return for some other raw material, and the manufactured goods were transported along with this trade.

No metal ingots of the Archaic period have been found anywhere yet, although an archaic wreck off Cap d'Antibes, France, ${ }^{8}$ has provided evidence of some sort of joint Etruscan-Punic venture, since it contained Etruscan amphorae and bucchero pottery as well as a Punic lamp. In the future it is likely that underwater finds of shipwrecks and better identification of Etruscan and Punic objects in all sites will greatly augment this picture. Certainly the work in progress at Carthage will have bearing on the foreign relations of these two cultures which are emerging only now from relative obscurity.

As it seems at present (and the synthesis here suggested represents only a general consideration of some of the evidence), Carthage and some Etruscan coastal cities (such as Caere) were generally allied by commercial agreements, since each could supply certain necessary commodities without jeopardizing the other's provincial markets. In 535 B.C. Carthage and Caere (at least) united voluntarily to drive out Greek competition for the Tyrrhenian Sea; in the early fifth century there was an important trading post on Caeretan soil (Pyrgi-Punicum). However, Etruscans seem not to have been at Himera or Motya to help their allies against the Sicilian Greeks, nor did a Carthaginian navy arrive at Cumae ( 474 B.C.) in time to support the Etruscan fleet against Hieron and the Western Greeks. In the mercenary wars of the fifth and fourth centuries, the nationality of the participants had little correlation with any previous alliances. Later, during the "Punic" Wars, the Etruscan cities gave relatively little support to either side but occasionally rebelled against their Roman garrisons when Hannibal was nearby and might conceivably profit from and reward their efforts. In general, however, these ancient states did not react with the idealism or consistency at-

\footnotetext{
${ }^{8}$ See Benoît: Gallia 16 (1958) 30-3I; Recherches sur l'hellénisation du midi de la Gaule (1965) pl. 41, fig. 6; and RStLig 22,1 (1956) 6, 20, fig. 15, and 22, fig. I6.

1 The main ancient sources on the Plataian monument are Hdt. 9.8 I and Paus. I0.13.9. The two most recent studies on the Serpentine column are by W. Gauer, Weihgeschenke aus den Perserkriegen (IstMitt Beiheft 2 [1968]) 75-96, pls. I-4; and A.M. Mansel, "La Colonne Serpentine d'Istanbul" (in Turkish) Belleten 34 (1970) 189-209, figs. I-22. This latter work has good photographs of the section of the shaft in Istanbul and reproduces many of the Turkish miniatures. Gauer has good illustrations of the shaft, the snaky head in
}

tributed to modern politics, and they appear to have honored treaties militarily only when they were mutually profitable. Their trade relations, much less complex than modern economical systems, presumably existed and flourished only in situations that offered both parties benefits with no compromises.

\section{LEIDEN}

Jean Macintosh Turfa

\section{THE PLATAIAN TRIPOD AND THE SERPENTINE COLUMN}

After the victory against the Persians at Plataia, the Greek allies set up a monument in Delphi which, according to ancient sources, consisted of a golden (or gilded) tripod atop a three-headed bronze snake, on whose coils the names of the participants in the battle had been engraved. The precious gold disappeared relatively soon, stolen by the Phokians in the fourth century ( 353 B.C.), and the serpentine column stood alone at the time of Pausanias's visit to the sanctuary, in the second century A.D. Constantine the Great took what remained of it to his new capital, Constantinople, where the bronze suffered further vicissitudes. Yet, in comparison with other ancient monuments, considerable evidence still remains for the Plataian trophy: in Delphi, the base in situ, missing only its topmost round block; in Istanbul, a good section of the serpentine shaft on the spina of the ancient hippodrome, and, in the Archaeological Museum, a substantial piece from the head of one of the snakes (figs. I-3). In addition, several drawings, wood-cuts, and Turkish miniatures show the serpentine column as it stood in Istanbul through the ages, and the piece is often mentioned by early travellers. Despite this relative wealth of evidence, the reconstruction of the total monument is still uncertain, and a recent study summarizing all arguments could only express preference, but no definite acceptance of previous solutions. ${ }^{1}$

All scholars apparently accept that not one but three snakes form the serpentine column. The basic point of controversy concerns the relationship of the tripod to the snaky heads. According to one reconstruction (ill. I, Solution I), the tripod itself was relatively small, and each of its feet rested on the head of one of the snakes. A second reconstruction (ill. I,

Istanbul, and what remains of the base in Delphi. Both works give previous bibliography. Gauer's uncertain opinion is expressed on p. 89; he conveniently summarizes all previous positions.

Vital statistics on the column are as follows: the height of the preserved 29 coils is $5.35 \mathrm{~m}$., with the last coil measuring ca. $0.63 \mathrm{~m}$. in diameter. The diameter on the extant topmost block, taken at the sinkings, is ca. $1.50 \mathrm{~m}$. 6 more coils are postulated to complete the shaft at the bottom, for an additional height of $0.38 \mathrm{~m}$., since the coils taper in thickness while increasing in diameter. The topmost step, now lost, had a presumed diameter of $2.48 \mathrm{~m}$., and a presumed height of $0.35 \mathrm{~m}$. 


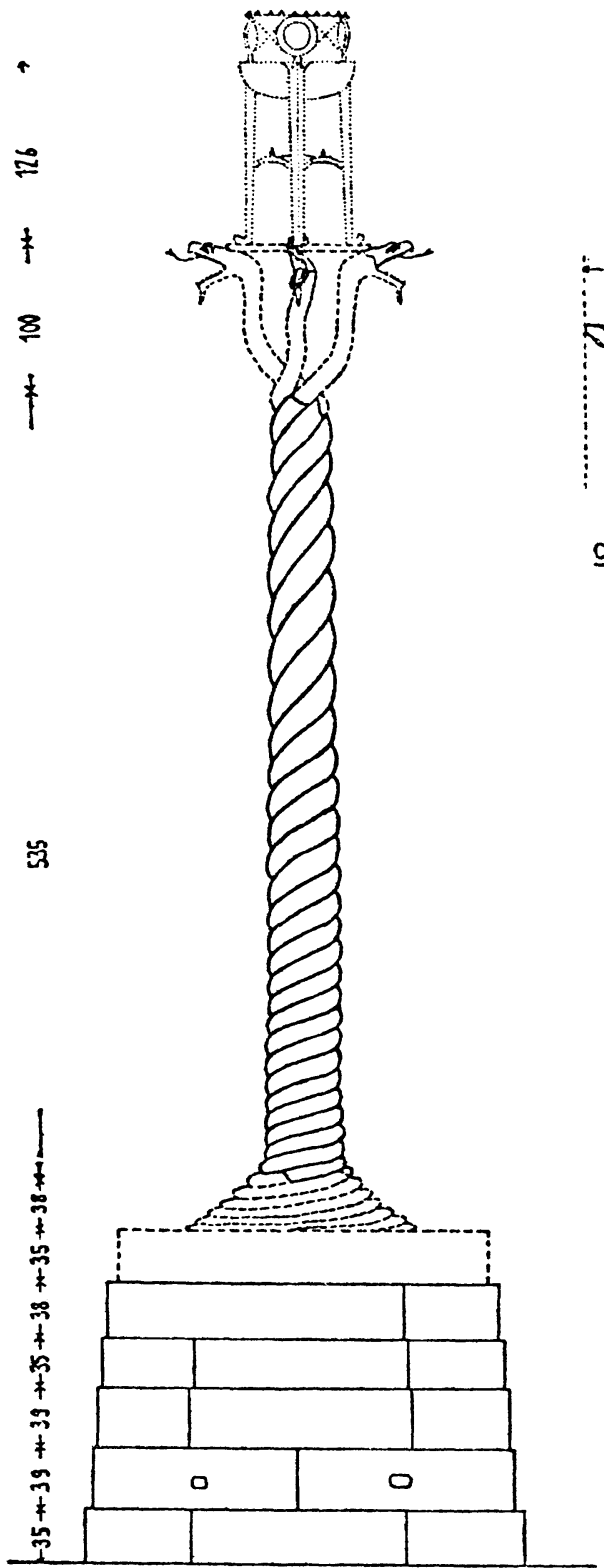

ㅁ Lösung I

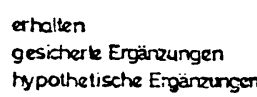

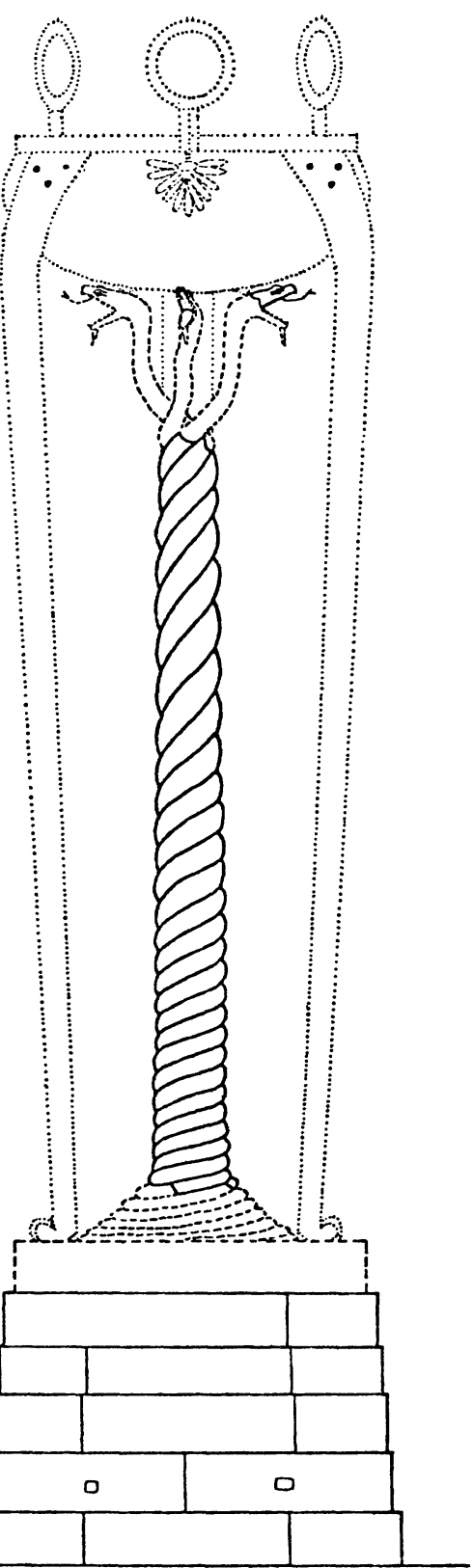

b Lösung II

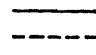

.................

ILL. I. The two reconstructions of the Serpentine Monument (after Gauer, fig. 4 on p. 8I) 
Solution II) visualizes the tripod as much larger, its legs extending all the way down to the stone base, with the bowl resting on the three serpents' heads. Given the extant and calculated height of the serpentine shaft, the second solution would require an enormous tripod, for which no secure attachment remains on the preserved stone base. The first solution, on the other hand, would minimize the importance of the tripod itself, despite the fact that ancient sources refer to the monument simply as "the tripod," virtually ignoring its picturesque support to concentrate on the obvious symbol of victory.

In his study, Gauer has examined anew the technical evidence for the most plausible restoration. What is preserved of the extant snake's head is basically the upper jaw, hollow cast and delimited by the palate below and the top surface of the head above. The piece is four-sided, since the flat top of the head is flanked by the two "cheeks" on which the cavities for the inserted eyes remain (fig. I). The edges of the fragment are largely irregular, as for a natural break, but on the left half of the upper surface one can still see the straight line for a rectangular cutting, in which Kluge noticed traces of hard solder (fig. 2). A similar straight edge for a smaller cutting appears at the break of the right side wall, mid-way up the "cheek," while the contour of an oval cutting is preserved in the lower wall of the fragment (fig. 3). A very small hole, first detected by Gauer against the snake's palate, is explained as the attachment point for the separately cast tongue, and this is undoubtedly correct. But the interpretation of the other, and larger, cuttings is more problematical. $^{2}$

The top rectangular hole can be lined up with the oval cutting at the bottom to contain an almost vertical object, which was supposedly anchored into position by a horizontal strut piercing the snake's right cheek. This explanation is the most economical since it coordinates all extant traces of cuttings into a single system; but is it likely that an object rectangular in section above the snake's head would turn into an oval rod by the time it pierced the lower surface? And can the cutting on the cheek really be for a transversal pin? Other possible explanations come to mind. The rectangular edges could have served for metal patches, as often required by air bubbles in ancient casting. Or the rear, missing part of the head could have been cast separately (to allow removal of the inner core), and then joined with the mortise-andtenon method, which requires similar regular indenta-

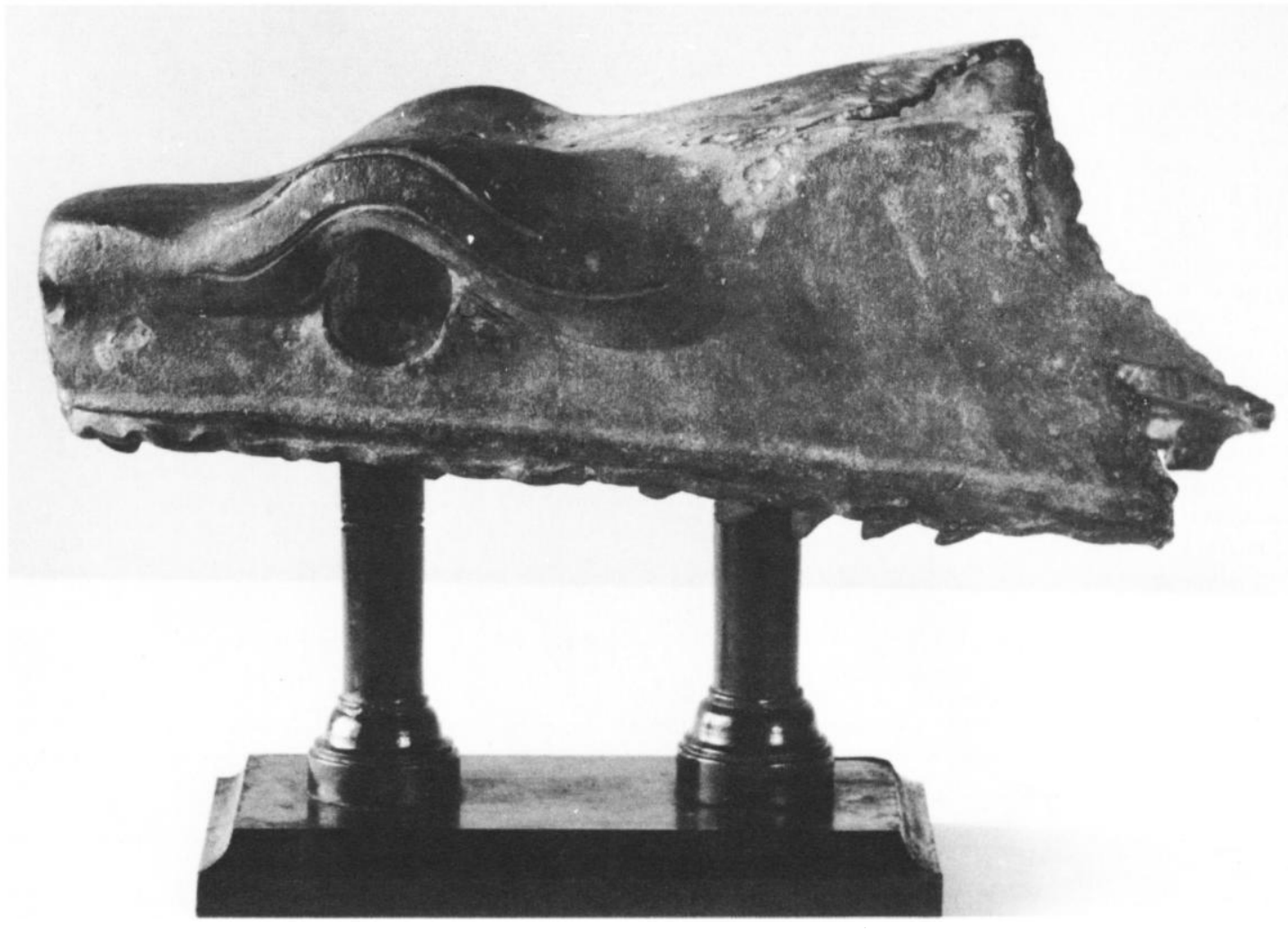

Fig. I. Serpent head in Istanbul (Photo DAI)

\footnotetext{
2 For these technical details, see Gauer (supra n. I) 79-80; K. Kluge's comments occur within a general article on ancient bronzes, IdI 44 (1929) 27 .
} 


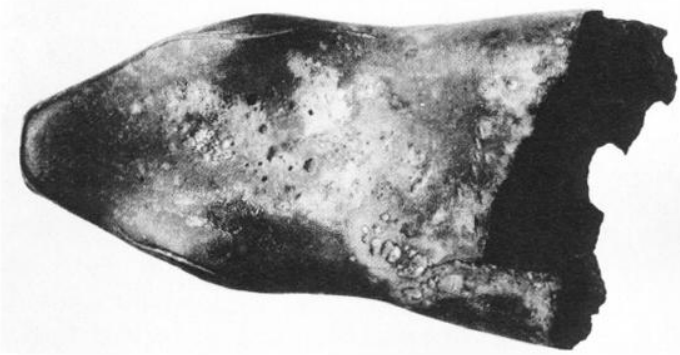

Fig. 2. Serpent head in Istanbul, top (Photo DAI)

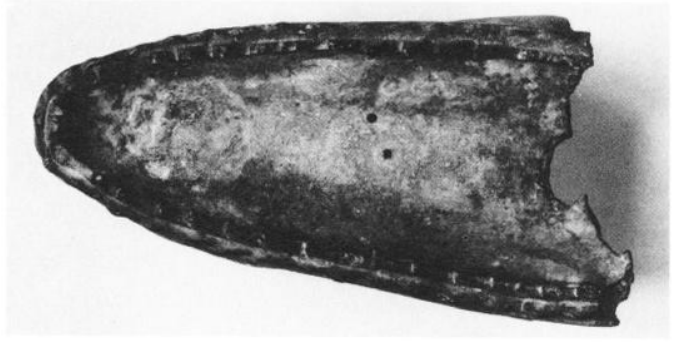

Fic. 3. Serpent head in Istanbul, bottom (Photo DAI)

tions and is often accompanied by solder. Finally, the traces of hard solder make me think that whatever rested in the upper cavity might have been added considerably later than $478 / 477$ B.C., when the monument was first cast and erected, since Greek bronze statuary is more usually pieced together without the help of extraneous metals. A solution lies at hand in the information that in Turkish times the serpentine column was transformed into a fountain, though it is perhaps hard to believe that each head spouted forth a different liquid (milk, wine, and water) ${ }^{3}$ If any or all of the cuttings in the snake's head are due to later reworking, or to patching and/or joining of the ancient cast, their evidence cannot be taken into account in reconstructing the position of the tripod over the animals' heads. We are therefore left with the appearance of the three snakes in the early drawings which, like numismatic representations, obviously

${ }^{3}$ On Greek joining techniques, see A. Steinberg in S. Doeringer et al., Art and Technology (M.I.T. Press, 1970) 5-35 and esp. 9-14; idem, in D. Mitten and S. Doeringer, Master Bronzes from the Classical World (Cambridge, Mass., 1967) I I-12. For a major example of the mortise-and-tenon method, see the arm of a large bronze statue, probably belonging to the so-called Philosopher from Antikythera, P.C. Bol, Die Skulpturen des Schiffsfundes von Antikythera (AthMitt Beiheft 2[1972]) 27, pl. r2:1. Since the "shaft" formed by the snaky bodies was apparently cast in one piece (Gauer [supra n. I] 78 and n. 329), it seems almost inevitable that the three heads should have been cast separately, to allow removal of the core and for greater ease in casting.

On the later destiny of the column and its use as a fountain, see Mansel (supra n. I) 199, and P. Levi, S.J., Pau- distort the actual features of a monument to suit the conception or the viewpoint of the artist.

Yet in all these representations, the long "necks" of the serpents branch out, leaving a considerable empty space in the center which faintly recalls the outline of a tripod bowl. I should therefore like to suggest one more reconstruction for the entire monument, which represents a compromise between Solution I and Solution II. The tripod's legs would extend past the shaft, perhaps even to the stone base, yet the bowl would rest not on the serpents' heads but on the entwined bodies, at the point where each animal uncoils itself. The long "necks" would then surround the bowl and project outwards presumably at, or somewhat above, the level of the tripod's rim, thus containing the cauldron as if in a basket.

The advantage of this reconstruction would be that it requires a smaller tripod than Solution II, yet larger than Solution I. But by far the strongest argument in its favor, to my mind, is that the appearance of the total monument would forcefully recall the Orientalizing cauldrons with griffin -or snake-attachments projecting at the rim. ${ }^{4}$ In the seventh-century pieces, these animal heads are true protomes, cut off at the base of the neck and connected with the body of the vessel. In the Plataian monument, this arrangement would have required that both elements be in the same medium, and gold (or gilding) was probably too expensive to allow it. In addition the snake, as the animal of Apollo, had a special importance at Delphi, which a serpentine column recognized and emphasized, though still subordinating the animal to the main symbol of victory, the tripod.

This allusion to greater antiquity in the total appearance of the monument would be perfectly in keeping with what we know about religious conservatism in Greek art and "archaism" in Greek dedications. At Delphi itself, as a recent reconstruction has shown, at least another monument recalled earlier renderings. The late-fourth-century Acanthus Column, which also originally supported a tripod, is surrounded by the statues of three dancing figures who raised their right arms toward the bowl in a caryatid gesture which obviously reminded the contemporary viewers of Daedalic perirrhanteria. The tripod legs

sanias' Guide to Greece (Penguin Books 1971) I, 44I, n. 89.

${ }^{4}$ For a cauldron with snake protomes as attachments from Samos, see U. Jantzen, Griechische Greifenkessel (Berlin 1955) pl. 49:1-2; see also pl. 58, nos. 186-89, from La Garenna, for the total effect, since certain griffin heads are very similar to serpents in general appearance.

Another, much earlier, example of the influence on other media exercised by such Orientalizing cauldrons with animal protomes can be found on the Protoattic Amphora from Eleusis with Perseus and Medusa (ca. 675 B.C.). The painter has patterned the Gorgons' heads after such vessels; see G.E. My-

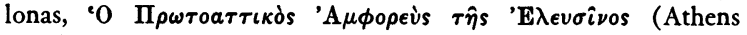
1957) 85-87 and English Summary, 122-23. Cf. also pls. 14-15. 
descended in between the dancers, thus creating a sort of niche or frame for the female figures, this rendering in turn evoking the appearance of the Lakonian tripods of the Severe period, where a divine figure stood between the legs and supported the bowl over its head. ${ }^{5}$

Were the legs of the Plataian tripod long enough to reach the stone base? And, if so, why were they not fastened to the blocks, since statically they were more important than the central support? Here too, various solutions come to mind. Perhaps the tripod's feet rested on the snakes' tails, thus coinciding with the latter and requiring only one set of fastening. Or, if this arrangement makes the tripod's legs too close to the central support, perhaps they were anchored only on the missing topmost block. In this case, the three cuttings visible in the middle round step would be not necessarily for the snakes' tails, but for vertical dowels fastening the upper to the intermediate block (ill. 2). It has been argued that the shape of the three

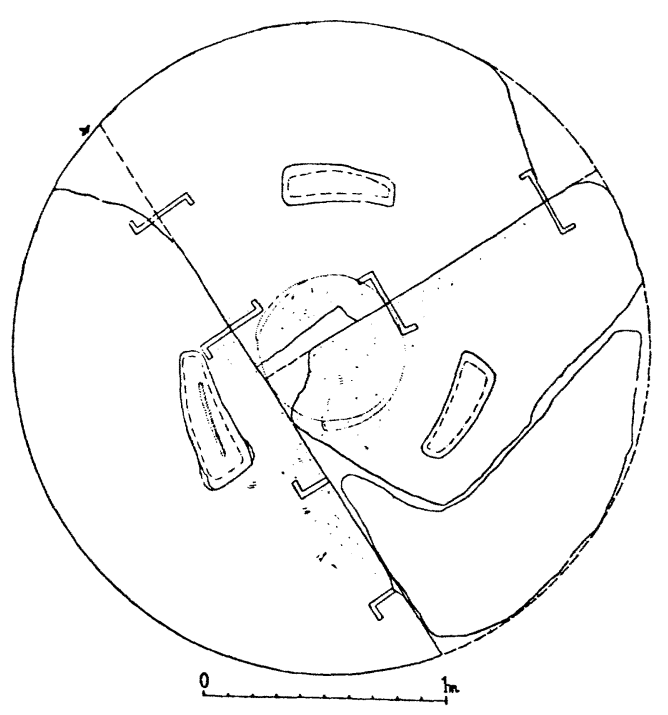

ILL. 2. Drawing of the topmost layer of the Delphic pedestal as preserved at present (after Mansel, fig. 8 [K. Stade])

\footnotetext{
5 For the recent reconstruction of the "Dancers" of the Acanthus Column, see J. Marcadé, "Les bras des danseuses," Mélanges helléniques offerts à Georges Daux (Paris 1974) 23954, especially 252-53. For Daedalic perirrhanteria, see, e.g. G.M.A. Richter, Korai (London 1968) nos. 3-13, figs. 3i-65. For gods' statues supporting tripods, see F. Chamoux, "Trépieds votifs à caryatides," $B C H 94$ (1970) 319-26. See also Gauer (supra n. I) 85-86.

P. Amandry, "Trépieds d'Athènes I: Dionysies," $B C H$ roo (1976) 15-93, has some discussion on the proportions of tripods; see also his p. 69, fig. 4I, for a reconstruction of the Acanthus column and of its tripod. Cf. also A.H. Borbein,
}

cuttings, each consistently tapering in the same direction, corresponds to the diminishing width of the snake's body, and that the great size and weight of the monument would require deeper fastening than the thickness of the topmost block. ${ }^{6}$ Yet I am not so sure that the irregular shape of the cuttings may not be due to later attempts to remove the metal of the dowels from the stone, nor do I see why, at that level, the shape of the attachment should correspond to the shape of the tails. Finally, one may even argue against the correctness of assuming that three tails existed. I wonder why the column, as preserved, should be interpreted as three intertwined snakes rather than as a single coiled serpent. Scrupulous logic in the rendering was not the ancient artist's main aim, and obviously the ancient viewers saw the Plataian support as one, though three-headed, animal. A similar effect -of a spiral column - could be obtained with a single coiled rope, without the misleading effect of the head finials. Were the snake one (as more appropriate allusion to Apollo), there would be no need for three tails, and the cuttings on the Delphic stones could be for the undoubtedly trine legs of the tripod. On the strength of all these considerations, I prefer to believe that the topmost block alone, now unfortunately missing, should be used to read the "footprints" of the entire monument, which cannot be safely reconstructed from the lower levels of its base.

It may also be objected that the ancient sources speak of the tripod as resting on the snakes' heads, while my proposed arrangement would make the heads only tangential to the bowl. Yet the ancient descriptions are approximate at best. A tripod caught between three necks could be described as being supported by the heads, especially since Herodotus's contemporaries would have been familiar with the monument itself, and by Pausanias's time the tripod proper had disappeared.

It is interesting to note that the commercial artists of modern Greece have reached approximately the same conclusion here advocated. The tripod here illustrated (fig. 4) is a small metal object which was bought at Delphi in 1971. For convenience sake, to avoid difficulty in casting and possible breakage, the snakes' heads are flattened against the tripod bowl, and the tripod legs are joined to the serpentine column

"Die griechische Statue des 4. Jahrhunderts v. Chr.," IdI 88 (1973) Anhang II, 194-21 2; Borbein has also some interesting comments on the tripod-like monument of the Nike by Paionios, 165-73, especially p. 169 .

${ }^{6}$ For these technical considerations, see Gauer (supra n. I) 76-77 and 82 , with previous bibliography. The dimensions of the cuttings on the topmost preserved block are as follows: length, ca. 0.40-0.50 m.; width (maximum), ca. 0.14 m.; depth, ca. 0.09-0.10 m. (Gauer [supra n. I] 76). Note that, in Solution II, the tripod legs are actually tangential to the snaky coils; were the tripod lower and smaller, proportions would allow that the legs rest on the snake itself. 


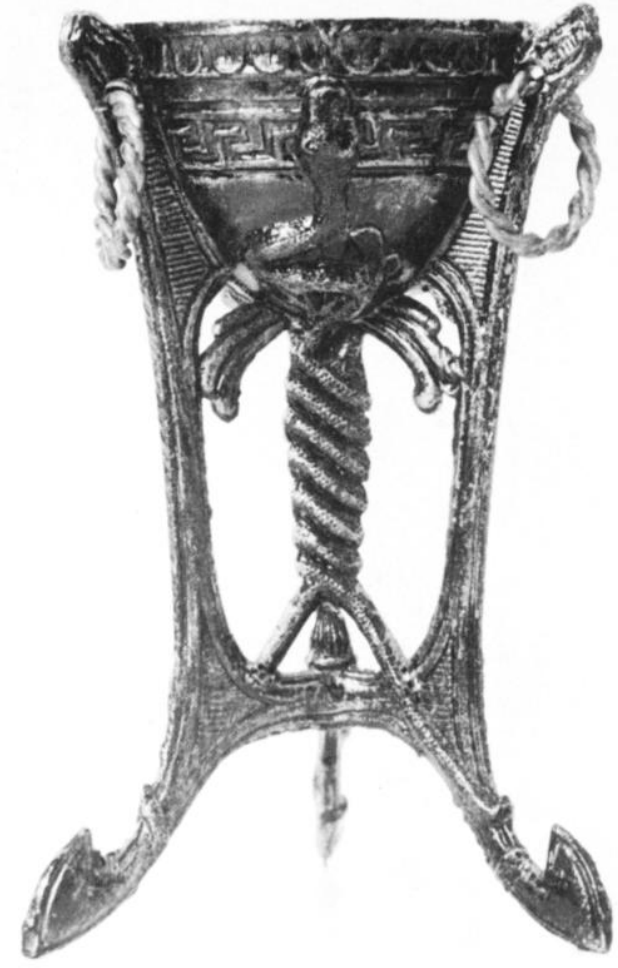

Fig. 4. The Delphic monument in a modern reconstruction (Photo K. Dimler, Bryn Mawr College)

in a rather improbable arrangement. But the basic conception is the same and may serve here to illustrate my suggestion more effectively than a drawing.

\section{BRUnilde Sismondo Ridgway}

\section{BRYN MAWR COLLEGE}

\section{THE PARTHENON FRIEZE AND THE SACRIFICE TO ATHENA ${ }^{1}$}

The subject of the Ionic frieze of the Parthenon has long been a matter of scholarly debate. Some scholars maintain that the frieze represents the procession which was part of the Greater Panathenaic Festival as it was celebrated quadrenially in Periclean Athens. Others point out that the composition of the procession on the frieze is different in some particulars from that attested by our numerous literary sources; certain elements of the procession, as described by the ancient authors, are lacking or somewhat altered in the frieze. ${ }^{2}$ One might reasonably conclude that the frieze

1 I am grateful to J.McK. Camp, E.B. Harrison, J.J. Pollitt, and H.A. Thompson for comments and suggestions on this paper.

2 The differences between frieze and testimonia were first noted by Peterson, cited by A. Michaelis (Der Parthenon [Leipzig I87I] 209), who nonetheless considered the frieze as a does not represent the historical procession but some other, more remote mythical event. This, however, is not entirely satisfactory, since the identity of that mythical event is obscure.

On the other hand, one can cleave to the traditional interpretation of the frieze as a representation of the procession as it actually appeared in the mid-fifth century B.C. Such a viewpoint, however, requires some explanation for the disagreements between the frieze and the literary testimonia. The following pages present a possible solution to this problem.

Some of the testimonia involved are late and possibly garbled. Two passages from the plays of Aristophanes, however, bear contemporary witness to a procession resembling the Panathenaic, and it is these with which we have chiefly to deal. The Birds was produced in $4 \mathrm{I} 4$ B.C., the Ecclesiazusae in 392; the Ionic frieze of the Parthenon was sculptured ca. 442438 B.C.

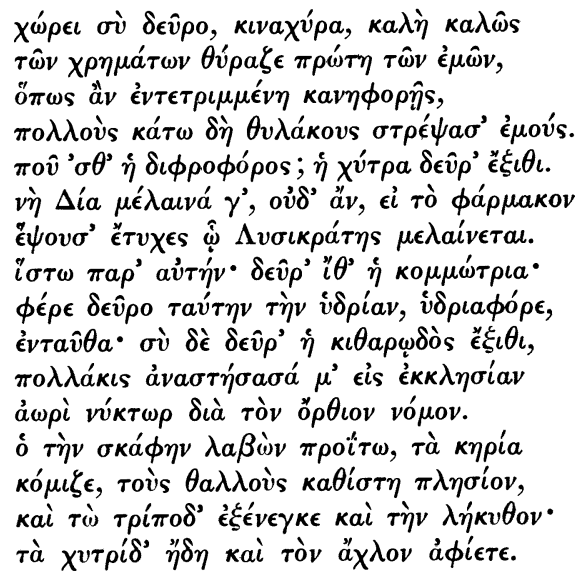

Ecclesiazusae 730-745

My sweet bran-winnower, come you sweetly here.

March out the first of all my household goods,

Powdered and trim, like some young basketbearer,

Aye, many a sack of mine you have bolted down.

Now where's the chair-girl? Come along, dear pot,

(Wow! but you're black; scarce blacker had you chanced

To boil the dye Lysicrates employs)

And stand by her. Come hither, tiring-maid;

And pitcher-bearer, bear your pitcher here.

You, fair musician, take your station there,

You whose untimely trumpet-call has oft

representation of the Panathenaic Procession. The differences are summarized by R. Holloway ("The Archaic Acropolis and the Parthenon Frieze," ArtB 48 [1966] 223), who draws the opposite conclusion, that the frieze does not represent the historical procession. See also L. Ziehen, "Panathenaia," $R E{ }_{1} 8$, 2, 2, col. 466 . 